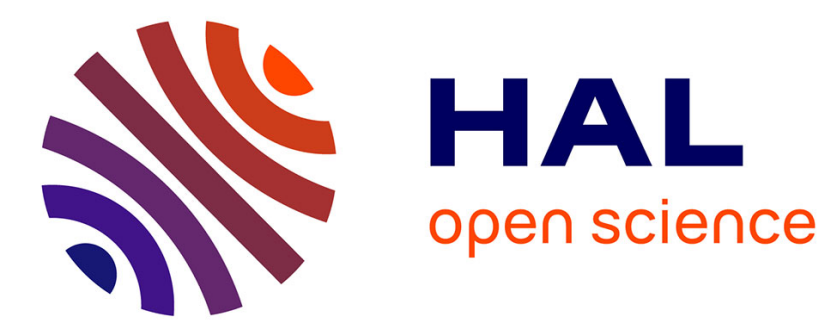

\title{
Cosmogenic 35S: A unique tracer to Antarctic atmospheric chemistry and the polar vortex
}

\author{
A. Priyadarshi, G. Dominguez, J. Savarino, M. Thiemens
}

\section{To cite this version:}

A. Priyadarshi, G. Dominguez, J. Savarino, M. Thiemens. Cosmogenic 35S: A unique tracer to Antarctic atmospheric chemistry and the polar vortex. Geophysical Research Letters, 2011, 38, pp.L13808. 10.1029/2011GL047469 . insu-00647185

\section{HAL Id: insu-00647185 \\ https://hal-insu.archives-ouvertes.fr/insu-00647185}

Submitted on 13 Aug 2021

HAL is a multi-disciplinary open access archive for the deposit and dissemination of scientific research documents, whether they are published or not. The documents may come from teaching and research institutions in France or abroad, or from public or private research centers.
L'archive ouverte pluridisciplinaire HAL, est destinée au dépôt et à la diffusion de documents scientifiques de niveau recherche, publiés ou non, émanant des établissements d'enseignement et de recherche français ou étrangers, des laboratoires publics ou privés.

$$
\text { Copyright }
$$




\title{
Cosmogenic ${ }^{35}$ S: A unique tracer to Antarctic atmospheric chemistry and the polar vortex
}

\author{
Antra Priyadarshi, ${ }^{1}$ Gerardo Dominguez, ${ }^{1}$ Joel Savarino, ${ }^{2}$ and Mark Thiemens ${ }^{1}$ \\ Received 15 March 2011; revised 13 April 2011; accepted 21 April 2011; published 7 July 2011.
}

[1] The cosmogenic radionuclide ${ }^{35} \mathrm{~S}$ (half life $\sim 87 \mathrm{~d}$ ) exists in both ${ }^{35} \mathrm{SO}_{2}$ gas and ${ }^{35} \mathrm{SO}_{4}^{2-}$ aerosol phase in the atmosphere. Cosmogenic ${ }^{35} \mathrm{~S}$ fulfils a unique niche in that it has an ideal half-life for use as a tracer of atmospheric processes, possesses a gas phase precursor and undergoes gas to particle conversion, providing a chronometer that complements other measurements of radiogenic isotopes of different half lives and chemical properties. Based on radiogenic ${ }^{35} \mathrm{~S}$ measurements and concomitant model calculations, we demonstrate that ${ }^{35} \mathrm{~S}$ is a unique tracer to understand stratospherictropospheric air mass transport dynamics and the atmospheric oxidation capacity on a short time scale. Reported are the first measurements of ${ }^{35} \mathrm{~S}$ contained in $\mathrm{SO}_{4}^{2-}$ aerosols (bulk and size aggregated) at Antarctica. ${ }^{35} \mathrm{SO}_{4}^{2-}$ concentrations at Dome C and Dumont D'Urville exhibit summer maxima and winter minima with a secondary winter peak. Higher oxidative capacity of the atmosphere and long range transport of mid latitude air increases ${ }^{35} \mathrm{SO}_{4}^{2-}$ activity in summer whereas a lack of air mass mixing coupled with low oxidant concentration in winter significantly decreases ${ }^{35} \mathrm{SO}_{4}^{2-}$ activity. A 3\% contribution from stratospheric ${ }^{35} \mathrm{SO}_{4}^{2-}$ into the free troposphere during stratosphere-troposphere air mass mixing accounts for the secondary winter ${ }^{35} \mathrm{SO}_{4}^{2-}$ peak. In the future, this work will be extended to ${ }^{35} \mathrm{~S}$ activity measurements of both gas and aerosol phases to further understand gas to particle conversion, vortex dynamics and trace polar stratospheric cloud sedimentation frequency. Citation: Priyadarshi, A., G. Dominguez, J. Savarino, and M. Thiemens (2011), Cosmogenic ${ }^{35}$ S: A unique tracer to Antarctic atmospheric chemistry and the polar vortex, Geophys. Res. Lett., 38, L13808, doi:10.1029/2011GL047469.

\section{Introduction}

[2] Antarctic ice core measurements provide one of the best records of extended global environmental change. Variation of past aerosol concentrations have been utilized to understand the interplay between atmospheric composition and climate [Alexander et al., 2002; Legrand and Mayewski, 1997]. An important requirement for interpretation of measurements is the need for a precise understanding of boundary layer chemistry and air mass transport into and within the Antarctic atmosphere.

[3] Antarctica's unique air circulation pattern significantly impacts its boundary layer chemistry. During winter,

\footnotetext{
${ }^{1}$ Department of Chemistry and Biochemistry, University of California, San Diego, La Jolla, California, USA.

${ }^{2}$ Laboratoire de Glaciologie et Géophysique de l'Environnement, CNRS, Université Joseph Fourier-Grenoble, Saint-Martin-d'Hères, France.
}

This paper is not subject to U.S. copyright.

Published in 2011 by the American Geophysical Union. an extreme surface temperature inversion leads to the formation of katabatic wind in which cold air from the Antarctic plateau persistently drains down into the steep slopes in the costal region [Parish and Bromwich, 2007]. The mass lost in the katabatic outflow is replenished by subsidence over Antarctica [Roscoe, 2004] which in turn is fed in the middle or upper troposphere by convergence of air into the cyclonic vortex [James, 1989]. The Antarctic atmosphere does not have a conventional tropopause during winter hence there is no barrier to stratospheric-tropospheric (S-T) exchange [Roscoe, 2004; Stohl and Sodemann, 2010]. In addition, the Antarctic atmospheric oxidative capacity is remarkably low in winter due to the lack of sun light [Mauldin et al., 2004; Jefferson et al., 1998]. The oxidation lifetimes of $\mathrm{SO}_{2}$ and DMS have been indirectly estimated using concentration measurements of non sea salt $\mathrm{SO}_{4}^{2-}$ and DMS [Preunkert et al., 2008; Legrand et al., 2001]. An extensive sampling of trace gases and aerosols is extraordinarily difficult particularly at inland sites. Multiple sources of $\mathrm{SO}_{2}$ and $\mathrm{SO}_{4}^{2-}$ complicate the estimation of $\mathrm{SO}_{2}$ oxidation life time. Here, we demonstrate that the cosmogenically produced radionuclide ${ }^{35} \mathrm{~S}$ is a unique tracer to understand $\mathrm{SO}_{2}$ oxidation chemistry, gas to particle phase conversion as well as $\mathrm{S}-\mathrm{T}$ air mass transport dynamics in the Antarctic atmosphere.

[4] Sulfur-35 (half life $t_{1 / 2}=87$ days) is a naturally occurring radionuclide generated by the cosmic ray spallation of argon [Lal and Peters, 1967]. Once produced, ${ }^{35} \mathrm{~S}$ rapidly oxidizes to ${ }^{35} \mathrm{SO}_{2}(\sim 1 \mathrm{sec})$ which can be removed from the atmosphere by wet and dry deposition. ${ }^{35} \mathrm{SO}_{2}$ may undergo gas and aqueous phase oxidation to produce ${ }^{35} \mathrm{SO}_{4}^{2-}$ aerosols which are removed from the atmosphere. Due to the higher production rate of ${ }^{35} \mathrm{~S}$ in the stratosphere [Lal and Peters, 1967] and longer residence time ( $\sim 1$ year) of both its gas and aerosol species, most ${ }^{35} \mathrm{SO}_{2}$ and ${ }^{35} \mathrm{SO}_{4}^{2-}$ produced in the stratosphere does not readily reach the troposphere before decaying to ${ }^{35} \mathrm{Cl}$ except during $\mathrm{S}-\mathrm{T}$ air mass exchange. Its short half life and bimolecular existence make it a sensitive tracer for understanding boundary layer chemistry and further defining the influx of stratospheric air into the troposphere on short time scales [Tanaka and Turekian, 1991; Brothers et al., 2010].

[5] In the past, many observations have been made to understand atmospheric transport into and within the Antarctic atmosphere using the cosmogenic radionuclides ${ }^{7}$ Be and ${ }^{10}$ Be as tracers [Feely et al., 1989; Savoie et al., 1992; Zanis et al., 2003]. Though important, these tracers are somewhat restricted (or less sensitive) as they readily attach to aerosol surfaces subsequent to their formation thus making their tropospheric lifetime primarily controlled by the wet scavenging of the carrier aerosol [Feely et al., 1989]. Thus they behave as solids rather than gases and may not be used to trace atmospheric gas phase chemistry directly. Here, we 


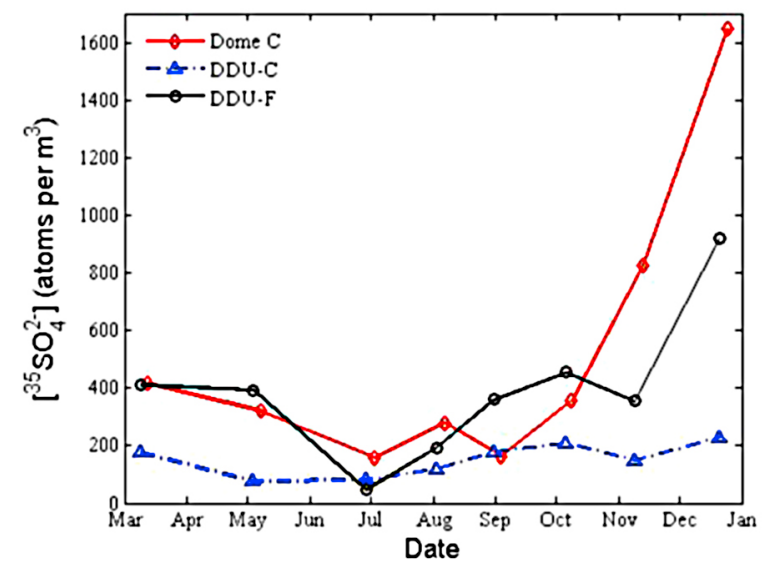

Figure 1. The variation in ${ }^{35} \mathrm{~S}$ activity contained in bulk sulfate aerosol measured at Dome $\mathrm{C}$ and in coarse $(\mathrm{C},>1 \mu \mathrm{m})$ and fine $(\mathrm{F},<1 \mu \mathrm{m})$ sulfate aerosol fraction at DDU. ${ }^{35} \mathrm{SO}_{4}^{2-}$ concentrations exhibit summer maxima and winter minima at both sites. A secondary peak in ${ }^{35} \mathrm{SO}_{4}^{2-}$ during late winter is also observed at both sites.

report the first measurements of ${ }^{35} \mathrm{~S}$ activities in sulfate aerosols simultaneously collected at two different stations in Antarctica.

\section{Experimental Details}

[6] Bulk and size aggregated aerosol samples were collected using a Hi-Volume aerosol sampler [Frey et al., 2009] with a time step of $\sim 7$ days at a typical flow rate of $\sim 1 \mathrm{~m}^{3} \mathrm{~min}^{-1}$, at Dome C (74.3S, 123E, $\left.3280 \mathrm{~m}\right)$ and Dumont D'Urville (DDU, 66.4S, $140.1 \mathrm{E}, 43 \mathrm{~m}$ ) respectively. A subset of filters (one per month) collected during 2009 was used for this study. Dome $\mathrm{C}$ and DDU have very different climatological conditions due to their inland and coastal locations respectively [Parish and Bromwich, 2007; KonigLanglo et al., 1998]. The samples were measured using a Wallac Quantalus 1220 Ultra Low Level Liquid Scintillation counter at UCSD following the methods developed by Brothers et al. [2010]. The measured activity was corrected for the background activity and the time elapsed between the sample collection and its measurement. The time correction made is to correct for the decay of the nuclide ${ }^{35} \mathrm{~S}$.

\section{Results and Discussion}

[7] ${ }^{35} \mathrm{~S}$ measurements in sulfate aerosols show a significant seasonal variation, with maximum activity in spring-summer (300-1600 atoms $\mathrm{m}^{-3}$ ) and minimum $\left(50-200\right.$ atoms $\left.^{-3}\right)$ in winter at both sites (Figure 1 and Table S1 in Text S1 of the auxiliary material $).{ }^{1}$ At DDU, fine aerosol $(<1 \mu \mathrm{m})$ possesses a higher activity than coarse $(>1 \mu \mathrm{m})$. This is probably due to its production in the upper atmosphere by gas $\left({ }^{35} \mathrm{SO}_{2}\right)$ to particle conversion whereas the activity found in coarse particles likely to originate from the uptake of a limited amount of ${ }^{35} \mathrm{SO}_{2}$ onto sea salt aerosol particles or from the coagulation of the fine ${ }^{35} \mathrm{SO}_{4}^{2-}$ aerosols. A secondary peak in ${ }^{35} \mathrm{SO}_{4}^{2-}$ is observed in late winter at both sites (Figure 1). The annual

${ }^{1}$ Auxiliary materials are available in the HTML. doi:10.1029/ 2011GL047469. average ${ }^{35} \mathrm{SO}_{4}^{2-}$ activity at Dome $\mathrm{C}$ is higher as compared to DDU probably because of the relatively higher production rate of ${ }^{35} \mathrm{~S}$ at that altitude and less diluted boundary layer.

\subsection{Box Model}

[8] A 4-box model (Figure 2) was developed to calculate ${ }^{35} \mathrm{~S}$ activities in $\mathrm{SO}_{2}$ and $\mathrm{SO}_{4}^{2-}$ at Dome C. ${ }^{35} \mathrm{~S}$ concentrations, at a given time, are the result of quasi equilibrium between ${ }^{35} \mathrm{~S}$ production rate and its subsequent oxidation to ${ }^{35} \mathrm{SO}_{4}^{2-}$ via ${ }^{35} \mathrm{SO}_{2}$ formation, air mass mixing dynamic, radioactive decay and scavenging processes which depend on local meteorological conditions. The equations governing the rate of change of ${ }^{35} \mathrm{SO}_{2}$ and ${ }^{35} \mathrm{SO}_{4}^{2-}$ concentrations are described in the auxiliary material. As described below, Model A was used to calculate the steady state concentration of ${ }^{35} \mathrm{~S}$ in $\mathrm{SO}_{2}$ and aerosol in the Antarctic atmosphere whereas Model B and Model $\mathrm{C}$ were used to calculate the seasonal variation in ${ }^{35} \mathrm{SO}_{2}$ and ${ }^{35} \mathrm{SO}_{4}^{2-}$ concentration.

3.1.1. Model A: Steady State Concentration of ${ }^{35} \mathrm{SO}_{4}^{2-}$

[9] Model A was run for 400 days with input parameters shown in Table S2 (SI) and ${ }^{35} \mathrm{~S}$ production rate as calculated by Lal and Peters [1967] to get the steady state concentration of ${ }^{35} \mathrm{~S}$ in both the gas and aerosol phases. The steady state concentrations of ${ }^{35} \mathrm{SO}_{2}$ and ${ }^{35} \mathrm{SO}_{4}^{2-}$ in the boundary layer (Box 1), as calculated by Model A, are: 189 and 728 atoms $\mathrm{m}^{-3}$ respectively (Figure $\mathrm{S} 1$ and Table $\mathrm{S} 3$ ). The ${ }^{35} \mathrm{SO}_{4}^{2-}$ concentrations are a factor of 18 lower than stratospheric ${ }^{35} \mathrm{SO}_{4}^{2-}$ concentration. At present, no measurements of ${ }^{35} \mathrm{~S}$ have been reported in the Antarctic atmosphere, although Brothers et al. [2010] reported the first simultaneous measurements of ${ }^{35} \mathrm{SO}_{2}$ at coastal and inland sites in California and showed that ${ }^{35} \mathrm{SO}_{2}$ concentrations vary from 9-184 atoms $\mathrm{m}^{-3}$ (coast)

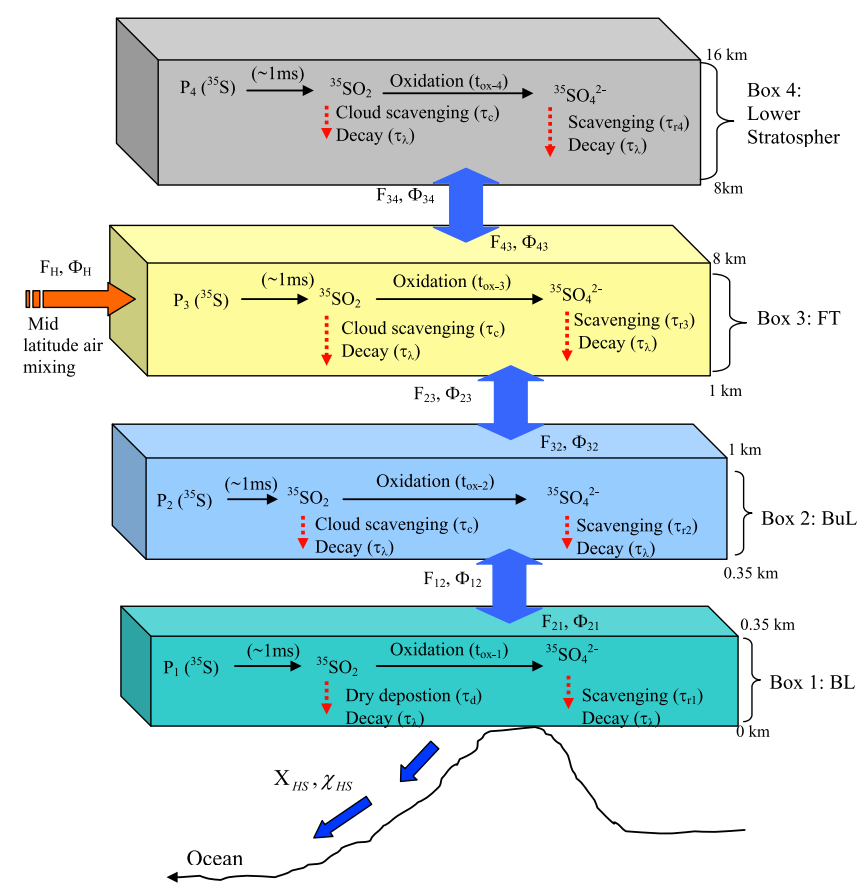

Figure 2. Description of 4-Box model showing sources and sinks of cosmogenic ${ }^{35} \mathrm{~S}$ at Dome $\mathrm{C}$. The atmosphere is divided into 4 different layers: Boundary layer (Box 1), Buffer Layer (Box 2), Free Troposphere (Box 3) and Lower Stratosphere (Box 4). See text for details. 


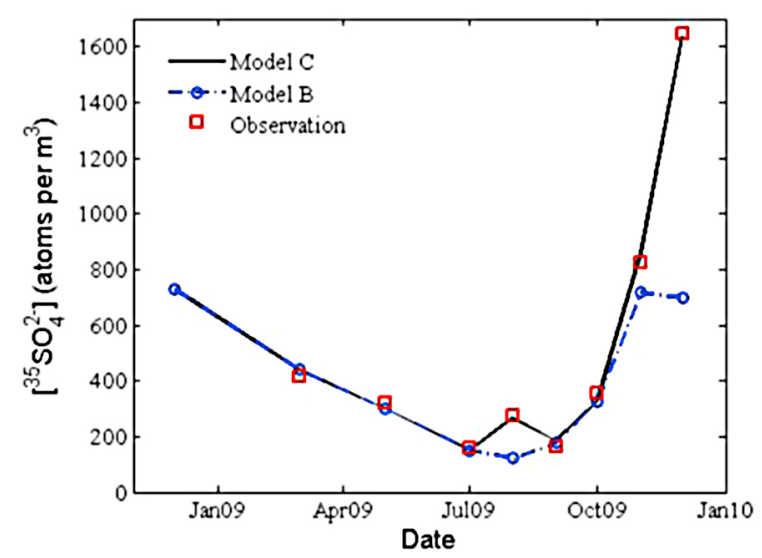

Figure 3. Model B calculates the seasonal variation in ${ }^{35} \mathrm{SO}_{4}^{2-}$ concentration at Dome $\mathrm{C}$ that agrees well with the observations (within 10\%) except for samples collected in August, November and December (Table S5). Model C estimates a $3-10 \%$ contribution from stratospheric air mass mixing into free troposphere to explain the difference in activities for these days.

and 436-915 atoms $\mathrm{m}^{-3}$ (inland), whereas the corresponding variation in ${ }^{35} \mathrm{SO}_{4}^{2-}$ concentration is from $100-200$ and $315-$ 1494 atoms $\mathrm{m}^{-3}$ respectively. Thus the model predicts steady state concentrations that appear to be reasonable and consistent with previous natural sample measurements.

\subsubsection{Model B: Seasonal Variation in ${ }^{35} \mathrm{SO}_{4}^{2-}$ \\ Concentration}

[10] Antarctic atmospheric conditions are very different in winter as compared to summer. Winter is characterized by the presence of a strong surface temperature inversion, lower oxidant concentrations, strong gravity driven katabatic winds, PSC formation, and higher S-T air mass exchange. These atmospheric conditions impact on the $\mathrm{SO}_{2}$ oxidation lifetime and the vertical and horizontal exchange mixing lifetimes to a large extent, therefore, these parameters were varied accordingly in Model B (see the auxiliary material for details). The initial summertime (Dec 08) concentrations of ${ }^{35} \mathrm{SO}_{2}$ and ${ }^{35} \mathrm{SO}_{4}^{2-}$ were set to the steady state concentrations calculated by Model A (Table S3). Model B was then run for 400 days with the varying parameters as described in Table S4. The model calculated ${ }^{35} \mathrm{SO}_{4}^{2-}$ concentrations agree with observations (within 10\%) except for the samples collected in August, November and December (Figure 3 and Table S5). It is evident from the model that the maximum concentration of ${ }^{35} \mathrm{SO}_{4}^{2-}$ in summer is due to the higher oxidative capacity of the atmosphere and long range transport of mid latitude air into free troposphere. In contrast during the Antarctic winter, a lack of air mass mixing between the vortex and extra-vortex air, aerosol scavenging coupled with the lower oxidation rate of ${ }^{35} \mathrm{SO}_{2}$ (less $\mathrm{OH}$ concentration), caused a significant decrease in ${ }^{35} \mathrm{SO}_{4}^{2-}$ activity.

\subsubsection{Model C: Stratospheric ${ }^{35} \mathrm{SO}_{4}^{2-}$ Contribution}

[11] As discussed, ${ }^{35} \mathrm{SO}_{4}^{2-}$ concentrations are expected to be low in the Boundary Layer during winter. However, a noticeable increase in the ${ }^{35} \mathrm{SO}_{4}^{2-}$ concentration was observed during mid winter (August) (Figures 1 and 3). Previous studies have shown that a sudden increase in the concentration of cosmogenic radioactive particles at the surface can be attributed to recent injections from the free troposphere or stratosphere [Feely et al., 1989; Zanis et al., 2003]. Model C calculates the contribution of stratospheric ${ }^{35} \mathrm{SO}_{4}^{2-}$ into free troposphere that mainly depends on the volume fraction of stratospheric air mass mixing into free troposphere during a tropopausal folding event (see details in auxiliary material). It shows that a total contribution of 3\% from stratospheric sulfate in the free troposphere would lead to the observed increase in ${ }^{35} \mathrm{SO}_{4}^{2-}$ in the boundary layer in August (Table $\mathrm{S} 5$ and Figure 3). Similar contributions of 4 and 10\% from stratospheric ${ }^{35} \mathrm{SO}_{4}^{2-}$ are estimated for samples collected in November and December. The settling out of particles $\left(\mathrm{HNO}_{3} / \mathrm{H}_{2} \mathrm{SO}_{4} / \mathrm{Ice}\right)$ associated with polar stratospheric clouds (PSC) may also contribute to elevated ${ }^{35} \mathrm{SO}_{4}^{2-}$ concentrations at the surface during winter (August), as has been observed in the case of nitrate and tritium $\left({ }^{3} \mathrm{H}\right)$ [Savarino et al., 2007; McCabe et al., 2007; Frey et al., 2009; Wagenbach et al., 1998].

\section{Conclusions}

[12] We report the first measurements of Antarctic cosmogenic ${ }^{35} \mathrm{~S}$ activity in sulfate aerosols. We show that ${ }^{35} \mathrm{~S}$ measurement in sulfate is a new method to quantify the stratospheric-tropospheric air mass mixing and the gasparticle conversion rates. ${ }^{35} \mathrm{SO}_{4}^{2-}$ concentrations are maximum in spring-summer due to higher oxidation rates of ${ }^{35} \mathrm{SO}_{2}$ in the boundary layer and long range transport of mid latitude air into the Antarctic troposphere as well as S-T mixing. A lack of air mass mixing between vortex and extravortex air coupled with the lower oxidation rate of ${ }^{35} \mathrm{SO}_{2}$, causes a significant decrease in ${ }^{35} \mathrm{SO}_{4}^{2-}$ activity in winter. A secondary ${ }^{35} \mathrm{SO}_{4}^{2-}$ peak in winter was observed at both stations and was attributed to a $3 \%$ of stratospheric air mass mixing into the free troposphere at Dome C. In the future work, ${ }^{35} \mathrm{~S}$ measurements coupled with multi oxygen isotopic measurements of sulfate would provide more detailed understanding of air mass transport and the boundary layer ${ }^{35} \mathrm{SO}_{2}$ oxidation chemical processes. An extensive sampling of both ${ }^{35} \mathrm{SO}_{2}$ and ${ }^{35} \mathrm{SO}_{4}^{2-}$ measurements could be used to resolve the effect that PSC sedimentation may have on ${ }^{35} \mathrm{SO}_{4}^{2-}$ concentration in Antarctica.

[13] Acknowledgments. We thank Martin Miller for his input on the manuscript and discussion and two anonymous reviewers of the manuscript for their insightful comments that improved this manuscript. Ivan Gaylor is gratefully acknowledged for provision of funds for the Quantalus.

[14] The Editor thanks A. J. Timothy Jull and an anonymous reviewer for their assistance in evaluating this paper.

\section{References}

Alexander, B., J. Savarino, N. I. Barkov, R. J. Delmas, and M. H. Thiemens (2002), Climate driven changes in the oxidation pathways of atmospheric sulphur, Geophys. Res. Lett., 29(14), 1685, doi:10.1029/2002GL014879.

Brothers, L. A., G. Dominguez, A. Abramian, A. Corbin, B. Bluen, and M. H. Thiemens (2010), Optimized low-level liquid scintillation spectroscopy of ${ }^{35} \mathrm{~S}$ for atmospheric and biogeochemical chemistry applications, Proc. Natl. Acad. Sci. U. S. A., 107, 5311-5316, doi:10.1073/ pnas.0901168107.

Feely, H. W., R. J. Larsen, and C. J. Sanderson (1989), Factors that cause seasonal variations in beryllium-7 concentrations in surface air, J. Environ. Radioact., 9, 223-249, doi:10.1016/0265-931X(89)90046-5.

Frey, M. M., J. Savarino, S. Morin, J. Erbland, and J. M. F. Martins (2009), Photolysis imprint in the nitrate stable isotope signal in snow and atmosphere of East Antarctica and implications for reactive nitrogen cycling, Atmos. Chem. Phys., 9, 8681-8696, doi:10.5194/acp-9-8681-2009. 
James, I. N. (1989), The Antarctic drainage flow: Implications for hemispheric flow on the Southern Hemisphere, Antarct. Sci., 1, 279-290, doi:10.1017/S0954102089000404.

Jefferson, A., D. J. Taner, F. L. Eisele, D. D. Davis, G. Chen, J. Crawford, J. W. Huey, A. L. Torres, and H. Berresheim (1998), OH photochemistry and methane sulfonic acid formation in the coastal Antarctic boundary layer, J. Geophys. Res., 103, 1647-1656, doi:10.1029/97JD02376.

Konig-Langlo, G., J. C. King, and P. Pettre (1998), Climatology of the three coastal Antarctica stations Dumont d'Urville, Neumayer, and Halley, J. Geophys. Res., 103, 10,935-10,946, doi:10.1029/97JD00527.

Lal, D., and B. Peters (1967), Cosmic ray produced radioactivity in the earth, Handb. Phys., 46, 551-612.

Legrand, M., and P. Mayewski (1997), Glaciochemistry of polar ice cores: A review, Rev. Geophys., 35, 219-243, doi:10.1029/96RG03527.

Legrand, M., J. Sciare, B. Jourdain, and C. Genthon (2001), Subdaily variations of atmospheric dimethylsulfide, dimethylsulfoxide, methanesulfonate, and non-sea-salt sulfate aerosols in the atmospheric boundary layer at Dumont d'Urville (coastal Antarctica) during summer, J. Geophys. Res., 106, 14,409-14,422, doi:10.1029/2000JD900840.

Mauldin, R. L., III, et al. (2004), Measurements of $\mathrm{OH}, \mathrm{HO}_{2}+\mathrm{RO}_{2}$, $\mathrm{H}_{2} \mathrm{SO}_{4}$, and MSA at the South Pole during ISCAT 2000, Atmos. Environ., 38, 5423-5437, doi:10.1016/j.atmosenv.2004.06.031.

McCabe, J. R., M. H. Thiemens, and J. Savarino (2007), A record of ozone variability in South Pole Antarctic snow: Role of nitrate oxygen isotopes, J. Geophys. Res., 112, D12303, doi:10.1029/2006JD007822.

Parish, T. R., and D. H. Bromwich (2007), Re examination of the near surface airflow over the Antarctic continent and implications on atmospheric circulations at high southern latitudes, Mon. Weather Rev., 135, 1961-1973, doi:10.1175/MWR3374.1.

Preunkert, S., B. Jourdain, M. Legrand, R. Udisti, S. Becagli, and O. Cerri (2008), Seasonality of sulfur species (dimethyl sulfide, sulfate, and methanesulfonate) in Antarctica: Inland versus coastal regions, J. Geophys. Res., 113, D15302, doi:10.1029/2008JD009937.
Roscoe, H. K. (2004), Possible descent across the "tropopause" in Antarctic winter, Adv. Space Res., 33, 1048-1052, doi:10.1016/S0273-1177(03) 00587-8.

Savarino, J, J. Kaiser, S. Morin, D. M. Sigman, and M. H. Thiemens (2007), Nitrogen and oxygen isotopic constraints on the origin of atmospheric nitrate in coastal Antarctica, Atmos. Chem. Phys., 7, 1925-1945, doi:10.5194/acp-7-1925-2007.

Savoie, D. L., J. M. Prospero, R. J. Larsen, and E. S. Saltzman (1992), Nitrogen and sulfur species in aerosols at Mawson, Antarctica, and their relationship to natural radionuclides, J. Atmos. Chem., 14, 181-204, doi:10.1007/BF00115233.

Stohl, A., and H. Sodemann (2010), Characteristics of atmospheric transport into the Antarctic troposphere, J. Geophys. Res., 115, D02305, doi:10.1029/2009JD012536.

Tanaka, N., and K. K. Turekian (1991), Use of cosmogenic ${ }^{35} \mathrm{~S}$ to determine the rates of removal of atmospheric $\mathrm{SO}_{2}$, Nature, 352, 226-228, doi:10.1038/352226a0.

Wagenbach, D., M. Legrand, H. Fischer, F. Pichlmayer, and E. W. Wolff (1998), Atmospheric near-surface nitrate at coastal Antarctic sites, J. Geophys. Res., 103, 11,007-11,020, doi:10.1029/97JD03364.

Zanis, P., et al. (2003), An estimate of the impact of stratosphere-totroposphere transport (STT) on the lower free tropospheric ozone over the Alps using ${ }^{10} \mathrm{Be}$ and ${ }^{7} \mathrm{Be}$ measurements, J. Geophys. Res., 108(D12), 8520, doi:10.1029/2002JD002604.

G. Dominguez, A. Priyadarshi, and M. Thiemens, Department of Chemistry and Biochemistry, University of California, San Diego, 9500 Gilman Dr., La Jolla, CA 92093, USA. (mthiemens@ucsd.edu)

J. Savarino, Laboratoire de Glaciologie et Géophysique de l'Environnement, CNRS, Université Joseph Fourier-Grenoble, 54 rue Molière BP 96, F-38402 Saint-Martin-d'Hères CEDEX, France. 